\title{
Perceptions of Tourism Stakeholders towards Tourism Industry in Nepal
}

\author{
Gele Rakpe Bhote ${ }^{15}$
}

\begin{abstract}
The main objective of this paper is to study the perceptions of major tourism stakeholders towards the tourism industry of Nepal and how it could be developed holistically. The Primary data was collected by researchers from a convenient sampling of 150 respondents using a structured questionnaire in the year 2014, and was analyzedthroughdescriptive and inferential statistics. The perception model for stakeholders was developed considering tourists, tour operators, hoteliers, tourist guides and the host community as the major actors. The study found no significant relationship between stakeholders and their perceptions on; number of stay days, promotional activities done by tourism associations and public agencies, mobilization of tourism revenues, and management and communication of tourism industry. Majority of the respondents perceived future prospects of the tourism industry as favourable. It was found that Nepal could extend tourists' stays and increase per day spending. Internet was found to be the most reliable source of travel information onNepal. Political factors scored the highest as an area where major improvements were needed. Tourism revenues were not properly mobilized for the development of the host community. The study concludes that there is a good future forthetourism industry if all stakeholders work cooperatively to solve the major issues that have a negative impact on tourism.
\end{abstract}

Keywords: Stakeholders' Perception, Tourism Stakeholders, Tourism Associations, Public Agencies, United Nations World Tourism Organization

\section{Introduction}

In the last decades, tourism has become one of the fastest growing economic sectors and a major player in The .international commercevolume of business for tourism is more significant and greater than other industry sectors such as oil, food production or automobile manufacturing, and has also become one of the main income sources for many developing countries. According to a report published in April 2014 by the United Nations World Tourism Organization (UNWTO) World Tourism Barometer, international tourist arrivals grew by 5\% in 2013, reaching a

15 Mr. Bhote is Sector Officer at Market System Development UNITERRA / CECI Nepal.

Corresponding email: gelek10@hotmail.com 
record 1,087 million visitors. UNWTO has forecasted that international arrivals will increase by $4 \%$ to $4.5 \%$ in 2014 . In 2013, Asia and the Pacific received 248 million international tourists, 15 million more than in 2012 which is a6 \% increase from the previous year.

While other South Asian countries including Sri Lanka, Maldives, and India showed growth in tourist arrivals, Nepal saw a $0.7 \%$ decrease in touristsin 2013 in comparison to the $9.8 \%$ growth in 2012. A total of 797,759 tourists visited Nepal in 2013 via air and surface routes as per the Economic Survey published by the Ministry of Finance, Nepal Government.

Mount Everest, Lumbini, World Heritage Sitesand National Parks are a few of the major attractions, which bring thousands of tourists to Nepal every year. Mountain climbing, trekking, rafting, jungle safari, bird watching, mountain biking, mountain flight, paragliding, bungee jumping, rock climbing and flying on ultra-light aircrafts are some of the major tourism activities in Nepal.

Tourism plays very important role for the overall economic development of Nepal. It is considered as the fastest growing industry in Nepal. As per the data published by World Travel \& Tourism Council in 2014, Tourism directly contributed $3.9 \%$ to Gross Domestic Product (GDP) and 3.2 \% to employment of Nepal in 2013. In the year 2014, tourism contributed $4.3 \%$ to GDP and $7.5 \%$ to employment in total. From the last few years, as per the data published by different authorities, arrival of tourists in the country has witnessed a rising trend. Many new hotels ranging from star rated to local lodges have come up in the last few years due to this increasing trend of tourists' arrival. Lonely Planet listed Nepal as one of the top 10 travel destinations in the world for 2015.

Despite Nepal's high potential in attracting a large number of tourists, the results have been less than satisfactory. There are many areas to be improved upon as per the changing time and changing needs of tourists. Because of developments in technology and busy lifestyle of people, demand and expectation of the tourists are changing day by day. In this competitive edge, tourists are demanding better service at their price. Hence, this research " Stakeholders' Perceptions of Nepal's Tourism Industry" plays a very important role in assessing the perceptual differences among key industry actors and strengthening the advocacy for better policy planning and programming to gain optimum benefit from tourism in terms of its contribution to GDP, Employment, and Exports and Investment.

The objective of this paper, therefore, is to study perceptions of tourism stakeholders toward the tourism industry of Nepal and how it could be developed holistically by answering the following question: 
What needs to be improved in the tourism industry of Nepal for maximizing the financial benefits in the days to come?

Null Hypothesis $\left(\mathbf{H O}_{1}\right)$ : There is no significant relationship between perceptions of Tourism Stakeholders on the length of tourists' stay in Nepal.

Null Hypothesis $\left(\mathbf{H O}_{2}\right)$ : There is no significant relationship between perceptions of Tourism Stakeholders on promotional activities done by Tourism Associations and Public Agencies.

Null Hypothesis $\left(\mathrm{HO}_{3}\right)$ : There is no significant relationship between perceptions of Tourism Stakeholders on development of Host Community through tourism revenues.

Null Hypothesis $\left(\mathbf{H O}_{4}\right)$ : There is no significant relationship between perceptions of Tourism Stakeholders on the management and communication of tourism industry.

\section{Literature Review}

The present study is related to the following published academic literatures. Chavan and Bhola (2013) found a difference among stakeholders' opinions in the case of destination satisfaction and the importance of available tourist services and amenities in the Satara district of India. But they considered only three actors of tourism industry namely tourists, hoteliers and tour operators and ignored other major actors to establish the perception gap which limits the scope of the study. Rahman (2012) stressed that most tourists' destinations elections are highly dependent on the destinations brand image, internet adoption which is then closely followed by previous customer satisfaction. Carson and et.al (2004) found significant deficiencies in the marketing activities aimed at tourist communication and education with regard to sustainable maintenance of the site environment at natural tourist sites. Dunn and Dunn (2002) highlighted the existence of negative attitudes by the majority of hotel workers toward Jamaicans and visiting people of color. Brida and et al (2011) found that future tourism development policies were supported by residents who viewed it as a positive impact on tourism. The findings also showed that native residents generally had negative views of the impact of tourism and these groups were less willing to support the tourism industry and its policies. However, their analysis was limited to residents only and since it was a case study, it is difficult to generalize the findings.

Zurick (1992) in his Nepal specific research could not clearly show how the economic benefits of adventure travel are distributed through Nepal's national and local economies. Epp (2013) found a link between stakeholder engagement on satisfaction and perceptions of Destination Management Organization (DMO) 
performance, but suggested further studies. Because of a small sample and a case study approach, her study was limited in its ability to produce generalize able results. Henderson (2011) in his research of the Philippines' highlighted that the improper arrangement of infrastructure in a country appears to be perceived negatively by international visitors when choosing a destination. He also highlighted other factors that influence inbound and outbound tourist in their travels, such as political instability, security and safety. Singh and et. al (2006) not only revealed that tourism is a dominant sector in the Jamaican economy but that it has replaced export agriculture and mining as the main engine of growth. The researchers recommend the repositioning of the tourism industry away from thesand, sea and sun mass model towards new forms of tourism that rely more on local resources. Shrestha (1998) recommended new product development, repositioning, maintenance and preservation of cultural heritages, good management of tourist, and increase inflight connectivity to give a boost to tourism industry in Nepal.

Since tourism is an important and interesting area of study, numerous researches worldwide have been done on the subject. However, a study on major stakeholders' perceptions of Nepal's tourism industry has not been examined. Therefore, this research attempts to assess the perceptions of major actors in Nepal's tourism industry, such as tour operators, hoteliers, tourist guides, host communities and tourists.

\section{Theoretical Concept}

Schiffman, L.G, and et al. (2011) define perception as the process by which an individual selects, organizes, and interprets stimuli into a meaningful and coherent picture of the world.

They describe perception as "how we see the world around us". Two individuals may be exposed to the same stimuli under the same apparent conditions, but how each person recognizes, selects, organizes, and interprets these stimuli is a highly individual process based on each person's own needs, values, and expectations. As per the authors the essence of successful marketing is the image that a product has in the mind of the consumer-i.e. it's positioning. Positioning is more important to the ultimate success of a product than its actual characteristics are, although products that are poorly made will not succeed in the long run on the basis of image alone. The core of effective positioning is the unique place that the product occupies in the mind of the consumer.

Chavan and Bhola's (2013) study "Gap Analysis of Stakeholders' Perception in Tourism Industry ", focuses on determining the stakeholders' profile and establishing the perception gap between tourists and service providers, mainly 
hoteliers and tour operators. The main objective of the study is to investigate the perceptual gap between the tourists who visited Satara district of India and tourism service providers' estimations. They found a difference among stakeholders' opinions in the case of destination satisfaction and the importance of available tourist services and amenities.

A model was developed to carry out the study based on the above understandings of perception.

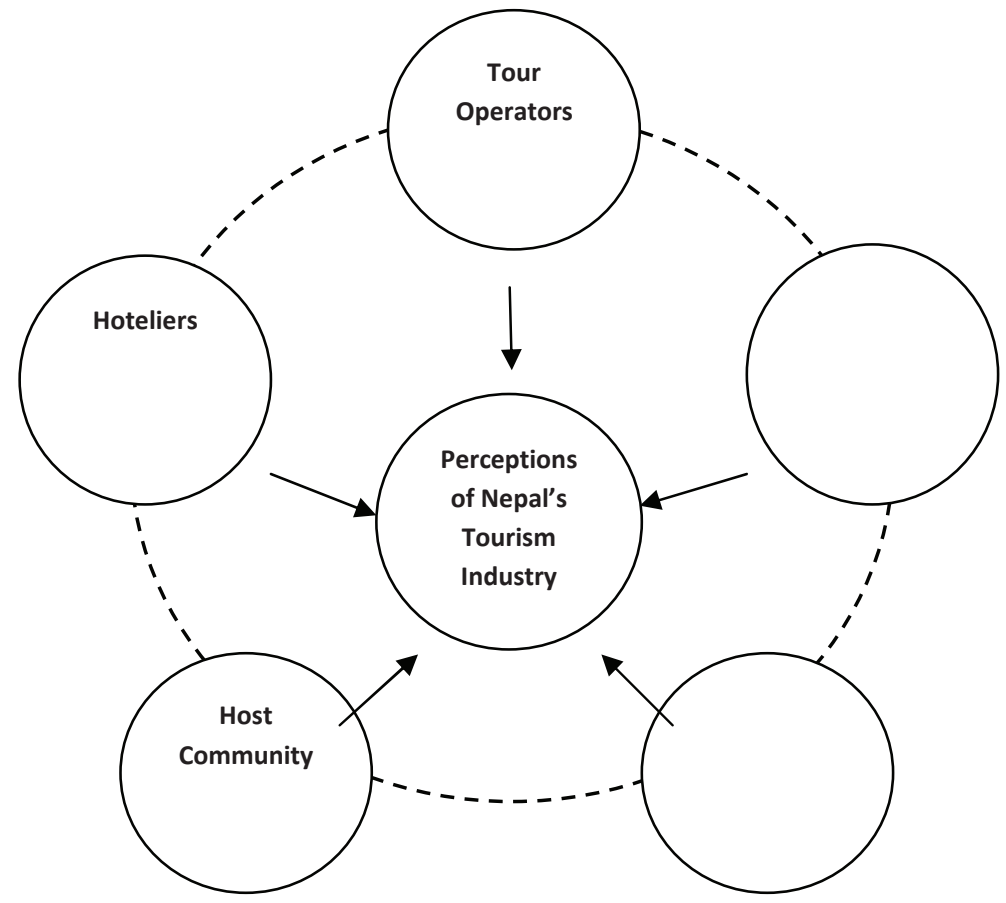

Perceptions of Nepal's Tourism Industry

Fig. No. 1: Conceptual framework

Chavan and Bhola's (2013) paper is key reference for the study. In this framework, Tour Operators, Hoteliers, Tourist Guides, Host Community and Tourists' perceptions determine the overall view of the tourism industry in Nepal. This is the perception of the tourism industry of Nepal in aggregate as perceived by major stakeholders like tourists, tour operators, hoteliers, tourist guides, and host community. 


\section{Tourists}

UNWTO defined tourist as " People who travel to and stay in places outside their usual environment for more than twenty-four (24) hours and not more than one consecutive year for leisure, business and other purposes not related to the exercise of an activity remunerated from within the place visited ".

\section{Tour Operators}

Tour operators are travel service providers that provide tourists with all their travel related needs. Beginning with information on the travel destination, tour operators than coordinate or book other relevant services such as hotel reservations, itinerary development, guiding services and transportation rentals. In Nepal, tour operators can be broadly classified as either trekking agencies or travel agencies. This study has only studied the perceptions of inbound tour operators. Inbound operators do not have control on demand and they are ground handling service providers whose stakes lie in the area of supply.

\section{Hoteliers}

Hotels provide accommodation for tourists with a specified rate. Hotels can be categorized as budget, boutique and star on the basis of theme, service and infrastructure. Hoteliers consist of people working in a hotel in any capacity who directly deal with tourists or as the owners of hotels.

\section{Tourist Guides}

Tourist guides are professionals who provide guiding services to tourists. In Nepal, tourist guides can be broadly categorized into either city guides or trekking guides. The Nepal Academy of Tourism and Hotel Management (NATHM) andthe Nepal Mountaineering Association (NMA) are the two authorized tourist guiding registration bodies.

\section{Host Community}

Host community are those who live in the vicinity of the tourist attraction and are either directly or indirectly involved with, and/or affected by tourism activities.

\section{Methodology}

\subsection{The Data}

This research is both descriptive and inferential. It tries to explore and analyze the perceptions of major tourism stakeholders to give a true picture to concerned authorities and tourism associations. It is also an applied study as it attempts to test the proven theory of marketing study. 
Everyone who is directly or indirectly involved in tourism business / profession and all tourists are the population of this study. One hundred and fifty samples were taken from major stakeholders like tourists, hoteliers, tour operators, tourist guides and host community in conducting the study. Non-probability convenience sampling was used to get required number of samples. Those samples were taken from the three main tourist destinations of the Kathmandu Valley namely Kathmandu, Bhaktapur and Patan as almost $90 \%$ of the tourists who visit Nepal visit those three places and all major tourism activities are coordinated from these three cities.

Both primary and secondary data were used to complete the study. Published reports, journals, articles, thesis, tourism statistics and online data were the sources for secondary information. Moreover, a structured questionnaire was used as a research tool to acquire first hand primary data from target groups. It took about two weeks to collect all required data.

Quality, length, language, order and physical appearance of the questionnaire playa very important role in getting accurate answers from respondents. All these components were considered at an optimal level when structuring the questionnaire. Explanatory information, basic information and classification information were retrieved from the questionnaire. The questionnaire was selfadministered and forwarded to respondents via email or in person.

Reliability and validity of the data was assured through good research design. To achieve valid results, the questionnaire was structured in such a way that it only asked required and relevant information from the respondents that fulfilled the research objectives. Ambiguous and irrelevant questions were avoided.

Table 11: Cronbach's alpha test for reliability

\begin{tabular}{|l|l|l|}
\hline Cronbach's Alpha & Cronbach's Alpha Based on Standardized Items & No. of Items \\
\hline 0.677 & 0.688 & 34 \\
\hline
\end{tabular}

Cronbach's alpha is 0.677 , which indicates a high level of internal consistency for likert scale questions. This test was conducted on likert scale questions used in the research questionnaire.

\subsection{The Methods}

All data acquired through questionnaire was coded in SPSS for data analysis purposes. Descriptive and inferential analyses were carried out on the basis of entered data. Frequency table, cross tabulation and descriptive statistics were used for descriptive analysis. Analysis of Variance (ANOVA) test was carried out to do inferential analysis. 


\section{Data Analysis and Presentation}

Both descriptive and analytical approaches were done to analyze research findings as per the research objectives with the help of SPSS.

\subsection{Descriptive Approach}

Table 2: perceptions of future prospects of tourism

\begin{tabular}{|l|l|l|}
\hline Future prospects of tourism & Frequency & Percent \\
\hline Good & 107 & 71.30 \\
\hline Average & 38 & 25.30 \\
\hline Bad & 2 & 1.30 \\
\hline Not known & 3 & 2.00 \\
\hline Total & 150 & 100.00 \\
\hline
\end{tabular}

$71.3 \%$ of the respondents perceived future prospects of tourism as good, $25.3 \%$ perceived it as average; only $1.3 \%$ perceived it as bad and $2 \%$ did not know. By this, it can be interpreted that the future prospects of tourism in Nepal are good as it was overwhelmingly viewed as good by $71.3 \%$ of the respondents.

\section{Table 3: Perceptions on promotional activities}

(Q. Tourism associations and public agencies are doing enough promotional activities)

\begin{tabular}{|l|l|l|}
\hline Response & Frequency & Percent \\
\hline Strongly Disagree & 24 & 16 \\
\hline Disagree & 47 & 31.3 \\
\hline Neutral & 46 & 30.7 \\
\hline Agree & 29 & 19.3 \\
\hline Strongly Agree & 4 & 2.7 \\
\hline Total & 150 & 100 \\
\hline
\end{tabular}

$31.3 \%$ of the respondents perceived that tourism associations and public agencies are not doing enough promotional activities. This finding implies that they should invest more time and effort in promoting the tourism industry of Nepal.

Table 4: Perceptions on development of the host community through tourism revenues

(Q. Revenues from tourists are well mobilized for the development of the host community)

\begin{tabular}{|l|l|l|}
\hline Response & Frequency & Percent \\
\hline Strongly Disagree & 18 & 12 \\
\hline Disagree & 36 & 24 \\
\hline Neutral & 45 & 30 \\
\hline Agree & 43 & 28.7 \\
\hline Strongly Agree & 8 & 5.3 \\
\hline Total & 150 & 100 \\
\hline
\end{tabular}


$30 \%$ of the respondents were neutral on whether tourism revenues like entry fees / permits are well mobilized for the development of the host community. Therefore, public agencies should develop effective mechanisms to utilize tourism revenues in the development of the host community.

Table 5: Perceptions on coordination between tourism associations and public agencies

(Q. There is a poor coordination between tourism associations and public agencies)

\begin{tabular}{|l|l|l|}
\hline Response & Frequency & Percent \\
\hline Strongly Disagree & 4 & 2.7 \\
\hline Disagree & 15 & 10 \\
\hline Neutral & 62 & 41.3 \\
\hline Agree & 34 & 22.7 \\
\hline Strongly Agree & 35 & 23.3 \\
\hline Total & 150 & 100 \\
\hline
\end{tabular}

$41 \%$ of the respondents were neutral on whether there is a poor coordination between tourism associations and public agencies. In the absence of coordination, it is impossible to achieve long term sustainable development in the tourism sector. It is high time that tourism associations and public agencies work in harmony in achieving larger results in the overall development of tourism rather than focusing on individual development.

Table 6: perceptions of internet and reliable source of travel information

\begin{tabular}{|l|l|l|l|}
\hline Stakeholders & Yes & No & Total \\
\hline Tour Operator & $23_{(76.67)}$ & $7_{(23.33)}$ & $30_{(100.00)}$ \\
\hline Hotelier & $18_{(60.00)}$ & $12_{(40.00)}$ & $30_{(100.00)}$ \\
\hline Tourist Guide & $23_{(76.67)}$ & $7_{(23.33)}$ & $30_{(100.00)}$ \\
\hline Host Community & $22_{(73.33)}$ & $8_{(26.67)}$ & $30_{(100.00)}$ \\
\hline Tourist & $23_{(76.67)}$ & $7\left(_{23.33)}\right.$ & $30_{(100.00)}$ \\
\hline Total & 109 & 41 & 150 \\
\hline
\end{tabular}

76.67 percent of the tour operators, tourist guides and tourists perceived internet as the most reliable source of travel information about Nepal and 23.33 percent sawit as not being reliable. Likewise, 60 percent of hotelier's perceived internet as the most reliable source of travel information about Nepal and 40 percent believed it was not. For the host community, 73.33 percent of them perceived internet as the most reliable source of travel information on Nepal and 26.67 percent thought it was not. 
Table 7: Perception on tourists' stay that can be lengthened as compared to 2013

\begin{tabular}{|l|l|l|l|l|l|}
\hline Stakeholders & n & Min & Max & Mean & Std. Dev \\
\hline Tour Operator & 30 & 12 & 30 & 21.17 & 5.86 \\
\hline Hotelier & 30 & 14 & 30 & 21.20 & 4.78 \\
\hline Tourist Guide & 30 & 12 & 30 & 19.87 & 6.41 \\
\hline Host Community & 30 & 13 & 90 & 26.13 & 14.14 \\
\hline Tourist & 30 & 12 & 60 & 21.57 & 8.86 \\
\hline Total & 150 & 12 & 90 & 21.99 & 8.83 \\
\hline
\end{tabular}

It is very encouraging for the tourism industry to see that the stakeholders believe Nepal can increase tourists' stays to 22 days. From above table, it can be inferred that Nepal should target long haul tourists and do its homework in developing suitable itineraries of about three weeks and focus on service quality with more holiday options.

Table 8: Perception on spending per day in comparison to $\$ 35$ per day in 2013

\begin{tabular}{|l|l|l|l|l|l|}
\hline Stakeholders & n & Min & Max & Mean & Std. Dev \\
\hline Tour Operator & 30 & 35 & 150 & 68.50 & 30.06 \\
\hline Hotelier & 30 & 40 & 250 & 73.33 & 45.91 \\
\hline Tourist Guide & 30 & 35 & 150 & 60.63 & 25.16 \\
\hline Host Community & 30 & 35 & 400 & 86.00 & 74.62 \\
\hline Tourist & 30 & 35 & 100 & 50.33 & 16.76 \\
\hline Total & 150 & 35 & 400 & 67.76 & 44.64 \\
\hline
\end{tabular}

In case of per day spending, stakeholders perceived that Nepal can increase tourist's spending about 68 dollar per day. It can be inferred that Nepal should focus more on quality than quantity and introduce more arrays of services and holiday options for tourists. 
Table 9: Perception on areas where major improvement is needed to attract more tourists

\begin{tabular}{|c|c|c|c|c|c|c|}
\hline \multicolumn{2}{|l|}{ Stakeholders } & \begin{tabular}{|c|} 
Rank for \\
surface \\
transportation \\
and road \\
safety \\
\end{tabular} & $\begin{array}{l}\text { Rank for } \\
\text { air safety }\end{array}$ & $\begin{array}{l}\text { Rank for } \\
\text { pollution } \\
\text { control }\end{array}$ & \begin{tabular}{|l|} 
Rank for \\
political \\
stability
\end{tabular} & $\begin{array}{l}\text { Rank for } \\
\text { personal } \\
\text { safety }\end{array}$ \\
\hline \multirow[b]{3}{*}{ Tour Operator } & Mean & 3.6 & 3.4 & 2.9 & 1.93 & 3.17 \\
\hline & $\mathbf{n}$ & 30 & 30 & 30 & 30 & 30 \\
\hline & Std. Dev & 1.22 & 1.35 & 1.35 & 1.23 & 1.39 \\
\hline \multirow[b]{3}{*}{ Hotelier } & Mean & 2.67 & 2.8 & 3.4 & 2.4 & 3.73 \\
\hline & $\mathbf{n}$ & 30 & 30 & 30 & 30 & 30 \\
\hline & Std. Dev & 1.27 & 1.35 & 1.38 & 1.25 & 1.48 \\
\hline \multirow[b]{3}{*}{ Tourist Guide } & Mean & 3.03 & 3.63 & 3.73 & 1.93 & 2.67 \\
\hline & $\mathbf{n}$ & 30 & 30 & 30 & 30 & 30 \\
\hline & Std. Dev & 1.22 & 1.07 & 1.26 & 1.41 & 1.37 \\
\hline \multirow[b]{3}{*}{ Host Community } & Mean & 3.13 & 3.2 & 3.37 & 1.9 & 3.37 \\
\hline & $\mathbf{n}$ & 30 & 30 & 30 & 30 & 30 \\
\hline & Std. Dev & 1.04 & 1.15 & 1.47 & 1.494 & 1.43 \\
\hline \multirow[b]{3}{*}{ Tourist } & Mean & 2.27 & 3.67 & 2.17 & 3.5 & 3.4 \\
\hline & $\mathbf{n}$ & 30 & 30 & 30 & 30 & 30 \\
\hline & Std. Dev & 1.48 & 1.09 & 1.18 & 1.36 & 1.25 \\
\hline \multirow[b]{3}{*}{ Total } & Mean & 2.94 & 3.34 & 3.11 & 2.33 & 3.27 \\
\hline & $\mathbf{N}$ & 150 & 150 & 150 & 150 & 150 \\
\hline & Std. Dev & 1.32 & 1.24 & 1.42 & 1.47 & 1.41 \\
\hline
\end{tabular}

Given factors in the above table are ranked from the scale of 1 to 5,1 being most needed and 5 being the least needed areas of improvement to attract more tourists in Nepal. Political stability scored the highest among given factors in aggregate. This finding implies that there is a need of significant improvement in the political environment of Nepal to attract more tourists.

\subsection{Analytical Approach}

One way the ANONA test was performed was to compare the means between stakeholder groups. Based on the result of the test, inferential analysis is also discussed. 
Table 10: Comparison of Stakeholders' perceptions of tourists' stay in Nepal

\begin{tabular}{|l|l|l|l|l|l|}
\hline Stakeholders & n & Mean & Std. Dev & F & P-Value \\
\hline Tour Operator & 30 & 21.17 & 5.86 & 2.30 & \multirow{2}{*}{0.06} \\
\cline { 1 - 4 } Hotelier & 30 & 21.20 & 4.78 & & \\
Tourist Guide & 30 & 19.87 & 6.41 & & \\
\cline { 1 - 4 } Host Community & 30 & 26.13 & 14.14 & & \\
\cline { 1 - 4 } Tourist & 21.57 & 8.86 & & \\
\cline { 1 - 4 } Total & 150 & 21.99 & 8.83 & & \\
\hline
\end{tabular}

Associated P-Value is 0.061 , which is greater than significance value 0.05 , and $\mathrm{F}$ Value is 2.30.The finding from the table illustrates that null hypothesis is accepted since P-Value is greater than significance value i.e. $0.06>0.05$. This shows that there is no significant relationship between stakeholder groups and their perceptions on tourists' stay in Nepal that can be lengthened.

Table 11: Comparison of Stakeholders' perceptions of promotional activities

\begin{tabular}{|l|l|l|l|l|l|}
\hline Stakeholders & n & Mean & Std. Dev & F & P-Value \\
\hline Tour Operator & 30 & 2.50 & 1.07 & \multirow{2}{*}{1.83} & \multirow{2}{*}{0.12} \\
\cline { 1 - 4 } Hotelier & 30 & 2.57 & 1.10 & & \\
\cline { 1 - 4 } Tourist Guide & 30 & 2.90 & 1.06 & & \\
\cline { 1 - 4 } Host Community & 30 & 2.27 & 1.05 & & \\
\cline { 1 - 4 } Tourist & 30 & 2.83 & 0.91 & & \\
\cline { 1 - 4 } & 150 & 2.61 & 1.05 & & \\
\hline
\end{tabular}

Associated P-Value is 0.12 , which is greater than significance value 0.05 , and $\mathrm{F}$ Value is 1.83.The finding from the table illustrates that null hypothesis is accepted since P-Value is greater than significance value i.e. $0.12>0.05$. This shows that there is no significant relationship between stakeholder groups and their perceptions on promotional activities done by tourism associations and public agencies.

Table 12: Stakeholders' perceptions of development of the host community

\begin{tabular}{|c|c|c|c|c|c|}
\hline Stakeholders & n & Mean & Std. Dev & $\mathbf{F}$ & P-Value \\
\hline Tour Operator & 30 & 2.87 & 1.07 & \multirow[t]{6}{*}{1.55} & \multirow[t]{6}{*}{0.19} \\
\hline Hotelier & 30 & 2.87 & 1.25 & & \\
\hline Tourist Guide & 30 & 2.67 & 0.96 & & \\
\hline Host Community & 30 & 2.83 & 1.23 & & \\
\hline Tourist & 30 & 3.33 & 0.92 & & \\
\hline Total & 150 & 2.91 & 1.10 & & \\
\hline
\end{tabular}

Associated P-Value is 0.19 which is greater than significance value 0.05 and $F$ Value is 1.55.The finding from the table illustrates that null hypothesis is accepted since P-Value is greater than significance value i.e. $0.19>0.05$. This shows that 
there is no significant relationship between stakeholder groups and their perceptions on development of the host community through tourism revenues.

Table 13: Perceptions of management and communication in tourism industry

\begin{tabular}{|l|l|l|l|l|l|}
\hline Stakeholders & n & Mean & Std. Dev & F & P-Value \\
\hline Tour Operator & 30 & 3.10 & 0.88 & \multirow{2}{*}{0.86} & 0.49 \\
\cline { 1 - 4 } Hotelier & 30 & 3.00 & 1.05 & & \\
\cline { 1 - 4 } Tourist Guide & 30 & 3.07 & 1.05 & & \\
\cline { 1 - 4 } Host Community & 30 & 3.33 & 0.92 & & \\
\cline { 1 - 4 } Tourist & 30 & 3.37 & 0.96 & & \\
\hline
\end{tabular}

Associated P-Value is 0.49 , which is greater than significance value 0.05 , and F Value is 0.86 .The finding from the table illustrates that null hypothesis is accepted since P-Value is greater than significance value i.e. $0.49>0.05$. This shows that there is no significant relationship between stakeholder groups and their perceptions on management and communication of Tourism Industry.

\section{Concluding Remarks}

The results of this study provide a better understanding of the perceptions held by major tourism stakeholders towards the current state of the tourism industry and how it could be developed holistically. 71.3 percent of the respondents perceived the future prospects of the tourism industry as favourable which encourages more investment from stakeholders to capitalize on good returns and gains. As per the tourism statistics published by the Nepal Tourism Board in 2013, average stay was 12 days and average spending was 35 dollars per day. However, stakeholders perceived that both the average stay and spending could be increased to 22 days and 67 dollars respectively. Hence, Nepal should try to reposition itself as a long haul travel destination with more dollars to spend in different activities. There is an urgent need to rework with e-marketing, as internet is considered to be the most reliable source of travel information on Nepal, especially with increments in internet coverage and the trend of using hand held devices in the search for information. All stakeholders should present Nepal in the best possible way with optimum utilization of different applications available for internet marketing. Political instability and strike were found to be the major areas of concern for travel planning and areas where major improvement is needed.

It is strongly recommended that Nepal should ensure political stability free of strikes and disturbances to attract more tourists in the future. The study recommends development of the host communities by mobilizing tourism revenue. This recommendation is inferred from the finding that stakeholders did not perceive tourism revenues as well mobilized for the development of the host 
community. It was found that there is a poor coordination between tourism associations and public agencies, and the tourism industry lacks proper communication and is not well managed. This finding implies that there is a need for better coordination and more effective dissemination of information to make information accessible for all concerned parties and to keep all stakeholders up to date on the latest developments in tourism.

As the study was carried out with a sample of size of 150 individuals based solely in the Kathmandu Valley (Kathmandu, Bhaktapur and Patan), an extensive study of other tourist destinations in Nepal, would further yield comprehensive findings.

\section{REFERENCES}

Brida, J. G., Disegna, M. and Osti, L. (2011). Residents' perceptions of tourism impacts and attitudes toward tourism policies in a small mountain community, Competence Centre in Tourism Management and Tourism Economics (TOMTE)

Carson, D., Gilmore, A., Ascengao, M. P. and Fawcett, L. ( 2004 ). Holistic Tourist Industry Marketing : Significant Deficiencies in Relation to Natural Tourist Sites, Journal of Marketing Theory and Practice, Vol. 12, No. 4, pp. 49-59

Dunn, H. S. and Dunn L. L. (2002).Tourism and Popular Perceptions: Mapping Jamaican Attitudes, Social and Economic Studies, Vol. 51, Issue. 1, pp. 25-44

Epp, A. (2013). Assessing the Impact of Stakeholders Engagement on Perceptions of DMO performance, ICRT Occasional Paper, n. 28, pp. 1-17

Henderson, J. C. (2011). Tourism Development and Politics in the Philippines, An International Multidisciplinary Journal of Tourism, Vol. 6, Issue. 2, pp. 159173

Lovelock, C., Wirtz, J. and Chatterjee, J. (2011). Services Marketing, $7^{\text {th }}$ Edition, Dorling Kindersley (India) Pvt. Ltd

Poudel, A. and Phuyal, R.K.(2016).An Analysis of foreign tourists' behavior and their satisfaction in Nepal. International Journal of Applied Business and Economic Research, 14(3): pp1955-1974..

Rahman, M. S. (2012).Exploring Tourists' Perception: The Case of Bangladesh. an International Multidisciplinary Journal of Tourism, Vol. 7, No. 1, pp. 81-98.

Shrestha, A. and Phuyal, R.K., (2016). A study on inbound tourist behavior of Nepal post-Gorkha earthquake" Advances in Economics and Business Management, 3(4): pp. 527-540. 
Shrestha, H. P. (1998).Tourism Marketing in Nepal, Unpublished Doctoral Thesis, Tribhuwan University, Nepal.

Singh, D. R., Birch, A. and McDavid, H. (2006). Impact of the Hospitality-Tourism sector on the Jamaican Economy, 1974 - 1993: An Input - Output Approach, Social and Economic Studies, Vol. 55, No. 3, pp. 183-207.

United Nations World Tourism Organization (2014).UNWTO World Tourism Barometer, United Nations World Tourism Organization, Vol. 12, pp. 1-3

Zurick, D. N. (1992). Adventure Travel and Sustainable Tourism in the Peripheral Economy of Nepal, Annals of the Associations of American Geographers, Vol. 82, No. 4, pp. 608-628. 